\title{
The Construal of Interpersonal Meanings in the Discourse of American Newspapers About Trumps' Travel Ban: An Appraisal Analysis
}

\author{
Shahad Mohammed Almayouf \\ Department of English Language and Translation, Qassim University, Saudi Arabia \\ E-mail: shahad.4808@hotmail.com
}

Received: July 16, 2021

Accepted: August 9, 2021

Published: August 25, 2021

doi:10.5296/ijl.v13i4.18864

URL: https://doi.org/10.5296/ijl.v13i4.18864

\begin{abstract}
The primary purpose of this study is to carry out and present an Appraisal analysis of the discourse of two reports published in the New York Times and the Washington Post newspapers. The specific objective is to identify and analyze the main attitudinal resources employed by the report's authors to construe and negotiate feelings with their audiences about the Muslim ban incident that was implemented during Trump's presidency of the United States. Moreover, the study explores the ideological differences from an Appraisal perspective about the travel ban between the selected newspapers. The study revealed that Appreciation resources were used more than other resources in the Washington Post, and the majority of them were addressing the travel restriction. On the other hand, the New York Times report made extensive use of both Judgment and Appreciation resources. In addition, all attitudes in the texts predicted ideological differences, but the Appreciation resources were the most critical predictor of ideological differences between them. This research reveals then which attitudes are more likely to reveal ideological differences.
\end{abstract}

Keywords: Systemic functional linguistics, Appraisal theory, Attitudinal resources, Interpersonal meaning, Political news, Travel ban

\section{Introduction}

Language is a powerful tool that reveals many of our opinions and some aspects of our identities in addition to our ideologies and beliefs, whether in spoken or written language, consciously or unconsciously. Therefore, its effectiveness is not only limited to enabling effective communication between individuals and conveying meaning and ideas. With language, we can share information about the world, we can create our worldview, and we can persuade each other as well. 
According to Halliday (1994), when we use language, we are always doing three things at once; meaning, we are in some way portraying the world, which he calls the ideational function of language, we are establishing, and negotiating our relationships with the people, which he calls the interpersonal function of language, also we are linking sentences and concepts together in specific ways to make cohesive and coherent texts, which he refers to as the textual function of language. These three functions of language constitute the most well-known model of grammar allocated in Critical Discourse Analysis (CDA), which is Systemic Function Grammar (SFG). All the language functions mentioned above are referred to as metafunctions of language (Thompson, 2014).

Whether we are aware of it or not, our language is never neutral; we always represent the world in our view in a certain way. In addition, our ideologies and assumptions influence our language use and word choices. In a written text, ideologies are always promoted to some degree. News, for example, is a form of writing style that has been studied by many linguists recently (Zhang, 2014; Jin, 2019; Sahputra, 2021), particularly political news, as it is a powerful discourse that is loaded with different ideologies. According to Martin and Rose (2007), access to these discourses through literacy pedagogies on discourse analysis has been a significant strand of work in Systemic Functional Linguistics (SFL). I will try to address the language of politics through which ideologies are expressed, and that requires a detailed analysis of language.

This paper aims to analyze two reports published in two different American newspapers, namely the New York Times and the Washington Post. Following Martin and Rose's (2007) (SFL) approach, this paper examines the writers' attitude in the two texts as represented by Martin and Rose's (2007) Appraisal framework. Furthermore, through the attitudinal resources' analysis, the study aims to identify the ideological differences revealed in both texts.

\subsection{Significance of the Study}

The significance of this research stems from the fact that it seeks to improve our understanding of how writers of newspaper reports interpret and discuss interpersonal meanings with their audiences. This research will add to the existing literature of the Appraisal framework as well as contribute to the understanding of newspaper discourses. This research is intended to illustrate the newspapers' politics in reporting a global issue, namely the travel ban. Furthermore, this research concentrates on linguistics and newspaper studies, therefore, it may be useful as a reference for language students or newspaper practitioners since it demonstrates how newspapers and reporters use language to convey specific meanings to audiences.

\subsection{Research Questions}

The study investigates the types of attitudinal devices employed by American newspapers to report news on Trump's travel ban and explains the meaning potentials based on the news reports' Appraisal resources. The following research questions are covered in this study:

1. How are the attitudinal devices employed in the Washington Post and New York Times' 
reports about the travel ban?

2. From the Appraisal realization, are there any ideological differences about the Travel Ban between the Washington Post and New York Times newspaper?

\section{Review of Literature}

\subsection{Theoretical Framework}

\subsubsection{Systematic Functional Grammar (SFG)}

Hart (2014) introduced us to different models of grammar that are derived from language and facilitate our realization of different functions of language like evaluation, representation, and legitimation function. In contrast with what Chomsky calls 'Generative Grammar' that emphasizes language in actual use and language construction, the proposed models of grammar are oriented to relating structure to communicative function. Their focal point is analyzing the meaning of language rather than its form (Hart, 2014). Grammars' models attempt to describe linguistic production with limited theories. They can be used as resources for discourse analysis, such as Critical Discourse Analysis (CDA). According to Hart (2014), CDA refers to "a particular form of discourse analysis which seeks to disclose the ideological properties of text, which might not be apparent without the assistance of a systemized framework" (p. 2). Hart (2014) points out, CDA is primarily concerned with 'ideology' that corresponds to 'world view' in which "ideologies are seen as normalized patterns of beliefs and values" (p. 3).

SFG is becoming more widely accepted as a practical framework for considering language as a resource for making meaning. One of Michael Halliday's most important contributions to linguistic research is his demonstration of how clause structures represent meaning (Martin \& Rose, 2003). Essentially, SFG examines language through the lens of social life to determine the 'real' function of interlocutors' linguistic choices (Fairclough, 2003). Therefore, it is beneficial to use SFG and its resources to figure out what communicators are attempting to say or why they use a specific technique to influence others.

SFG is primarily concerned with social influences and other factors related to the text and context. It seeks to discover how language can be used to "construe reality and enact social relationships" as a "theory of choice," as well as provide analysts with a concise explanation of how language influence is used (Webster, 2009, p. 1). In summary, SFG covers a broad range of topics, including social relations, linguistic signs, contexts, and other vital issues. Language is seen as a medium for communication rather than a set of rules.

\subsubsection{Appraisal, the System of Expressing Our Feelings and Attitudes}

Emerging within the domain of the 'interpersonal' social metafunction of language in SFG, 
Appraisal theory is a framework formulated and proposed by Martin and White (2005) to explore how people describe interpersonal meanings in texts. It focuses on how speakers display and intensify emotions and how they could use multiple voices in their discourses. Moreover, it provides techniques for analyzing evaluation and stance in texts in a systematic way. The main concern of Appraisal framework is the social function of these resources, rather than the ways writers convey their feelings and take positions (Peter \& White, 2011). It seeks to systematize a varied selection of linguistic resources that speakers and writers use to negotiate evaluations with their interactors and build unity around shared meaning. The Appraisal framework encompasses three key subsystems, namely, attitude, graduation, and engagement. The resources used to negotiate emotions, assess people's character and actions and evaluate the value of things are referred to as attitude. Moreover, we use graduations as lexical resources to "tell how strongly we feel about someone or something," and we use engagement to introduce "additional voices into a conversation by projection, modularization, or concession" (Martine \& Rose, 2003, p. 54). The main focus of this study is on the attitude system for mapping feelings in English texts.

\subsubsection{Attitude Subsystem}

The most effective tools for the analysis can be found in the attitude system. Painter (2003) defines attitude as "a domain concerned with the linguistic expression of positive and negative attitudes.” (p. 184). According to Martin and Rose (2007), attitudes have to do with evaluating things, people's personalities, and emotions, such evaluations can be amplified as well. In addition, the attitude could be the writer's own attitude, or it could be attributed to a third part of the text. Attitude, in turn, is the core of three semantic fields generally known as Affect, Judgment, and Appreciation.

Regarding Affect, it is the most typical way of expressing how we feel about things; it encompasses the manifestation of our emotional responses (Thompson, 2014); for example, I like her, which is a simple expression of the writer's feelings. Affect may also be classified as positive or negative; this is determined by whether the emotions are regarded as good or bad in a culture. Further, Affect can be expressed in a variety of lexicogrammatical structures, including participant descriptions and attributes (Affect as quality), process descriptions (Affect as a process), and modal adjuncts (Affect as a comment) (Hart, 2014). Affect, according to Martin and White (2005), groups "emotions into three big sets having to do with un/ happiness, in/ security, and dis/satisfaction” (p. 49). Unlike Judgment and Appreciation, which are concerned with the characteristics of the appraised individual, Affect is concerned with the appraiser's emotions (Thompson, 2014).

As for judgment, it is primarily concerned with human behaviors and actions. According to Martine and White (2005), it refers to the speaker's or writer's assessment of other people's actions in light of social norms and morality; that is, making judgments on people's behaviors by comparing them to existing social norms as the best ways to behave in a given situation like he is respectful. The system of Judgment is divided into two main categories: social esteem and social sanction, both of which can be sub-categorized and polarized into positive and negative 
outcomes (Hart, 2014). It is further subdivided into the following five categories: normality, ability, tenacity, veracity, and property.

Appreciation is concerned with the speaker or writer displaying their evaluation of things, including object and process, and making judgments on them; for example, it is a beautiful painting. Appreciation, according to Martin and White (2005), accounts for "meanings construing our evaluations of 'things,' especially things we make" (p.56). The three variables that comprise the Appreciation framework, which are reaction, valuation, and composition. Reaction deals with both the impact of the product and its perceived quality. Composition, in turn, is related to the balance and the complexity of an object. As for the valuation, it simply looks at whether the overall design works and worthwhile.

Attitudinal meaning can be realized in two ways: directly or indirectly. Direct or inscribed realizations are utterances in which the attitudinal evaluations are overtly indicated by some kinds of evaluative lexis, usually adjectives. On the other hand, implicit or evoked attitudes are typically realized through the selection of ideational meanings, lexical metaphors, and non-core vocabulary items (Martin \& White, 2005).

\subsection{Related Studies}

\subsubsection{Previous Studies of Appraisal Framework}

Several researchers have used Appraisal framework to evaluate the attitudes resources of various genres. Siyou and Zhongwen (2018), for example, conducted a comparison study between Xi Jinping's and Donald Trump's speeches at the World Economic Forum in 2017 and 2018, based on Martin's Appraisal framework. Their study looked at how they express ideology in their speeches and how they use language tools to organize feelings, judgments, and appreciations. The findings of their study revealed that, regarding attitude, positive words exceed the number of negative words in both speeches.

Furthermore, Alhabib (2020) examined Barack Hussein Obama's Inaugural Address 'New Era of Responsibility' through the lens of the Appraisal framework. According to the study findings, Obama's speech was full of optimism and an optimistic outlook on America's future. Moreover, the president used open language while remaining formal; he used affirmative and clear sentences to minimize the gap between him and the audience.

previous studies have tended to focus on a variety of other genres and discourses as well. De Souza (2006), for example, provides an interesting Appraisal analysis of 24 national anthems written in the English language to identify and examine the critical attitudinal resources used by anthem writers to express and negotiate feelings with their audiences. The study revealed that the writers of national anthems tend to portray their evaluative stance by direct representation of attitudinal meanings. Further, it was found that there is a high frequency of inscribed judgmental evaluations in the national anthems that were justified by the social aims of the national anthems, which are to unite people around common universal values and character. The findings also revealed that national anthem writers use Affect and Appreciation principles to unite readers around shared emotional bonds for the country. 


\subsubsection{Previous Studies of News Discourse}

Many researchers have made significant advances in the study of news discourse recently (e.g., Zhang, 2014; Jin, 2019; Sahputra, 2021). Appraisal framework is commonly used in discourse analysis as a language evaluation tool. Some Australians who specialized in SFG have turned their attention to the study of news discourse. They discovered that news reporters and analysts have distinct identities and distinct forms of assessment tools, narrative styles, and voice intervention techniques (Huang, 2020). According to Rui and Jingxia (2018), the news is the primary source of knowledge for the public, as it helps in the creation of people's beliefs and ideologies. Moreover, it is an ambiguous reflection of the reporters' attitudes or views, with their responsibility behind them. In other words, reporting is not always as objective as people believe. It is an oblique expression of the reporters' attitudes or opinions. Therefore, the interpersonal meanings of news discourse can be expressed by examining language from the Appraisal theory perspective, namely, attitude, engagement, and graduation.

News discourse is an essential discourse study that is part of discourse research. The analysis of international news discourse began with van Dijk's famous works, namely News as Discourse and Racism and News Reports (Rui \& Jingxia, 2018). Pana and Kosickib (1993) point out news discourse about public issues is constructed when it comes to its functions. At the same time, it is critical in the development of public policy concerns. As a result, news discourse is regarded as a social-cognitive process since it has three components: reporters, sources, and the public in general.

Based on SFG Xu (2015) examines some of China's daily news using the three metafunctions of SFG: ideational, interpersonal, and textual. He discovers that political news has distinct characteristics in terms of ideational, interpersonal, and textual function. Furthermore, network news achieves objectivity and consistency by transitivity structures and third-person pronouns in the news.

This study is distinctive in that it is attempting to bridge the gap between previous studies and focusing on the newspaper genre, by exploring the interpersonal meanings from the appraisal framework in the discourse of American newspapers about one of the most important incidents that occurred during Trump's presidency, which is the Travel Ban.

\section{Method}

\subsection{Corpus to Be Analyzed}

\subsubsection{The New York Times}

The New York Times, a morning daily newspaper published in New York City, has long been the United States' newspaper of record and one of the world's great newspapers. Its strength lies in its editorial quality; it has never been the most popular newspaper (The New York Times, 2020). In 2017, the same year the travel ban was executed, the New York Times newspaper published a report written by the editorial board with the title 'Donald Trump's Muslim Ban Is Cowardly and Dangerous' in which some implications of this ban were 
presented (see Appendix A). For more details about the selected report, see Table 1.

Table 1. Donald Trump's Muslim Ban Is Cowardly and Dangerous Report

\begin{tabular}{ll}
\hline Paragraphs & 11 paragraphs \\
Sentences & 38 sentences \\
Words & 798 words \\
\hline
\end{tabular}

\subsubsection{The Washington Post}

The Washington Post is a morning daily newspaper published in Washington, D.C. It is the most widely circulated newspaper in the United States capital and is widely regarded as one of the best in the world (The Washington Post, 2020). It is one of the American newspapers that also wrote about Trump's travel ban and criticized it, as it published a report titled 'Trump's Travel Ban Caused Heartache and Suffering. For What?' that criticized Trump's policies and the implication of this ban on the refugees and American citizen lives (see Appendix B). In addition, the selected report touched upon Biden's policies to deal with the travel ban. For more details about the selected report, see Table 2.

Table 2. Trump's Travel Ban Caused Heartache and Suffering. For What?

\begin{tabular}{ll}
\hline Paragraph & 18 paragraphs \\
Sentences & 62 sentences \\
Words & 1,081 words \\
\hline
\end{tabular}

\subsection{Procedure}

The corpus picked out for this study is written documents. The information was obtained online from the newspapers' official websites. To choose the appropriate reports to be effectively analyzed, the researcher read about the incident of Trump's travel ban in depth. After that, the researcher identified two well-known platforms of American news to collect the reports from. After identifying the suitable newspapers, the researcher read many reports related to the incident; then, two reports were selected depending on their suitability with the study's objective from the researcher's perspective.

Besides the researcher's personal interest, the abundance of news reports of various ideologies was a factor in the researcher's decision to use political reports as the corpus for this study. Therefore, working on newspaper report content and political language and discourse that include frequent use of metaphors and linguistic phrases will give a clear and thoughtful discursive and linguistic analysis.

The researcher will now go through the subsystems of attitudes in greater detail, as well as provide an outline of how the New York Times and the Washington Post employ them. 


\section{Results and Discussion}

While investigating how the New York Times and the Washington Post newspapers wrote about Trump's travel ban, it was observed that they all declined Trump's policy and criticized his executive order about banning citizens from different Muslim countries from traveling to the United States. It was also noted that the rejections and the criticisms stem from different perspectives. Some have criticized the ban from a purely political point of view, and others criticize it because of its implications on social relations and citizens, focusing mainly in some situations of refugees.

This section will present the findings of the data analysis, as well as related discussions, which centered on the Appraisal devices considering Attitudes. Moreover, it describes how the reports' writers employ Affect, Judgment, and Appreciation to convey their attitude and feelings about the controversial travel ban initiated by President Trump. The first question in this study sought to explore how the attitudinal devices employed in the selected newspapers about Trump's travel ban. In this section, each newspaper will be discussed separately.

\subsection{Attitudinal Resources in the Washington Post Newspaper}

According to the Washington Post report, some implications of the travel ban have been discussed, such as its impact on the social relationships of the affected refugees. The writer mentioned the suffering and the experiences that group of people went through from different countries that included in the travel ban, focusing on Yemeni, Iraqi, Iranian citizens, and how the travel ban that banned their countries' citizens from entering the United States affected their relationships with their parents and family showing sympathy for them. In addition, the writer discussed the stance of Biden, the newly elected President, and the American citizens of the travel ban.

\subsubsection{Affect System}

Starting with the report title that indicates the writer's reaction and his emotions towards the travel ban. The analysis showed that the title contains a direct negative Affect by showing the physical harm the travel ban caused to the refugees, as can be seen in the example below:

\section{1- Trump's travel bans caused heartache and suffering. For what?}

As previously stated, Affect refers to the interpretation of emotions related to an individual's emotional state, dispositions, and reactions to emotional phenomena. The use of Affect resources in a text is a clear indication of speakers' attitudes, and it is a useful strategy for positioning listeners and negotiating communication with them. Individuals can have either good or bad feelings; therefore, Affect can be positive or negative. In addition, Attitudinal meanings can be realized either directly or indirectly.

The use of lexical metaphors is one technique for indirectly expressing attitudinal meanings. According to Martin and White (2005), the use of lexical metaphors is an example of provoking attitude, since it has the ability to reveal an attitudinal reaction in readers. In the Washington Post report, the banned countries and their citizens have metaphorically represented as casualties of the travel ban initiated by Trump, see the examples below: 
1- War-torn Yemen.

2- Their hopes took a severe blow after Trump announced his ban.

3- People whose lives were thrown into disarray by a flick of Trump's pen.

Furthermore, Hart (2014) divides the system of Affect into three categories: un/happiness, in/security, and dis/satisfaction. Happiness is concerning the modes constructed broadly as feelings of happiness or sadness. It is worth noting that most of the Affect resources in the Washington Post report indicate unhappiness feelings expressed indirectly. In the mentioned examples, we can notice the writer's negative Affect and sympathy from the expression war-torn Yemen that revealed the writer's awareness of the war implications on Yemen and the depth of his sorrow about it. In the following example, we can notice how the writer portrays the disappointing experience that faced an Iranian refugee whose father worked as a translator for the United States military in Iraq, and she with her family were waiting for the United States to give her father a service. As for the third example, the writer expressed his sympathy for the negative changes that affected the refugees' lives and his dissatisfaction with the travel ban that Trump ordered with no regard for such consequences.

On the other hand, the writer expressed his negative feeling and his displeasure of the travel ban directly, describing it as a pain and its impact on refugees' lives, which turned into chaos. See the excerpt:

1- Americans either have no qualms exacting such pain on strangers, or no idea about the misery the travel bans caused.

\subsubsection{Judgment System}

Speakers use Judgment tools to evaluate social behavior in terms of socially established moral, legal, and personal norms. Furthermore, Judgment is concerned with two broad categories - Judgment of social esteem and Judgment of social sanction, and the concepts of Judgment are divided into five subcategories in the system of judgment, namely, normality, capacity, and tenacity, which related to social esteem, and veracity, property, that related to social sanction. Like Affect, Judgment can be expressed explicitly or implicitly (Martin \& White, 2005).

However, such an 'implied' attitude raises significant theoretical and analytical problems. In other words, when moving from direct to indirect activation, we move from 'semantics' to 'pragmatics,' from meanings inscribed in the text to meanings operating only in context. Therefore, Peter and White (2011) believe that further researches are needed to provide a systematic account of the processes that operate in this 'invocation' process.

After showing the refugees suffering from different countries and the implications of the travel ban, and the writer's feelings and reaction towards it, he moved to those who ordered the ban execution. The analysis showed that the texts contain several negative and positive judgments that were employed indirectly through which various ideologies were passed on. See the examples: 
1- Trump invoked national security to justify these sweeping prohibitions.

2- President Biden repealed the ban on his first day in office.

3- 55 percent of Americans approve of Biden repealing the travel bans.

4- Americans either have no qualms exacting such pain on strangers, or no idea about the misery the travel bans caused.

The first example reveals how the writer portrayed Trump as a deceitful person (social sanction) who invoked national security to justify the travel ban and the prohibitions. In contrast, President Biden was positively portrayed by mentioning his reaction, which is the rescission of the travel ban, which was not acceptable, neither by the American citizen nor the writer (social sanction). In addition to President Biden, American citizens were also portrayed positively by mentioning that more than half of the citizens approved the rescission decision (social sanction).

Additionally, the writer mentioned some critiques about Trump's arguments from Justice Sonia Sotomayor, who employed direct negative judgments (social sanction) concerning Trump's justification for the ban and his motives. See the following examples:

1- Trump's ban masquerades behind a facade of national-security concerns.

2- It was motivated by anti-Muslim animus.

\subsubsection{Appreciation System}

Positive and negative evaluations of objects, texts, persons, systems, and natural phenomena are expressed by Appreciations, which are interpersonal resources. According to Martin and White (2005), the framework of Appreciation is organized around three variables: reaction, composition, and valuation. We can distinguish between positive and negative Appreciation, just as we can between Affect and judgment. In other words, we can differentiate between properties we value and those we do not. The reaction category is further divided into reaction impact and reaction quality, while the composition category is divided into composition balance and composition complexity. However, in the current report, only the writer's reaction was employed to appreciate the travel ban.

Since the main subject of the Washington Post report is the travel ban and its negative implications, almost the majority of the Appreciation resources are directed to it by employing direct negative appreciations. See the following examples:

1- The former president had campaigned on the extremist promise.

2- Trump's executive order was found to be discriminatory.

3- This ban was nothing less than a stain on our nation.

4- It is impossible to prove that America was made safer by inflicting this torment on whole communities abroad.

5- Americans either have no qualms exacting such pain on strangers, or no idea about the 
misery the travel bans caused.

Notice the example (1) and (2) that indicate the writer's reaction (quality) towards the ban and his portrayal of it as extremism and discriminatory, as it only includes Muslims' countries. Moreover, the use of lexical metaphors is one technique for implicitly expressing attitudinal meanings. According to Martin and White (2005), the use of lexical metaphors is an example of provoking attitude, since it has the ability to reveal an attitudinal response in readers. The third example, which is a quotation of Biden's national security adviser's words, also includes an implied negative Appreciation of the ban. Thus, through metaphorical representations of the ban as a 'stain' and the feelings of outrage and shame normally associated with it, compliant listeners are directed toward a negative attitudinal response.

Further, Appreciation can be expressed by the reaction. Martin (2000) contends that reaction values are related to the extent to which an entity, process, or phenomenon captures our attention and the emotional impact it has on us. In other words, reaction evaluations are expressions of our liking or dislike for the objects, entities, and phenomena under consideration. Inscribed evaluations of reaction were employed in the examples (4) and (5) to evaluate the ban's negative consequences in negative terms like torment, misery, and pain.

To sum up, the writer employed different attitudinal resources that show the personal meaning of the incident. However, the Appreciation resources were employed more than other resources, as most of the Appreciation resources were about the travel ban, and most of them were negative and direct Appreciation. Moreover, almost all of the Affect resources employed in the text were negative Affect and expressed directly as well. Regarding Judgment resources, the analysis showed they were the least used system that employed scarcely in the text. The majority of the Judgment resources were negative and expressed indirectly.

\subsection{Attitudinal Devices Used to Realize Attitude of the New York Times}

Similar to the Washington Post, the New York Times report also concentrated on the implications of the travel ban on the inflicted families. Moreover, the writer strongly criticized Trump's policies as a President and criticized his reckless administration and its effect on the United States' relations with its allies, especially the Middle East countries. In addition to the political criticism, the writer discussed the seriousness of this decision on national security and the potential to provoke extremist groups due to the inflammatory tone and religious extremism that appeared in Trump's order. This section will discuss how the editorial board opposed Trump's travel ban and how the attitudinal resources are employed in the text.

\subsubsection{Appreciation System}

The majority of terms in this report express a negative Appreciation sense because the writer has used several words to explain the ban from his perspective and how the travel ban impact individuals' lives. Consider the following examples:

1- They had outrun carnage and despotism in their homelands to arrive in a singularly hopeful nation. 
2- This ban will also disrupt the lives and careers of potentially hundreds of thousands of immigrants.

3- That the order, breathtaking in scope and inflammatory in tone.

4- The order lacks any logic.

5- The unrighteousness of this new policy.

6- The first casualties of this bigoted, cowardly, self-defeating policy.

We can see from these examples that the number of negative Appreciation terms is more than the number of positive Appreciation words, and that the majority of them are adjectives and verbs. Since this is a political topic, many adjectives explain the travel ban like bigoted, cowardly, and unrighteousness, indicating that it is an oppressive phenomenon. However, some positive Appreciation terms, such as hopeful, which is used to characterize the United States, have appeared in example 1, intending to portray the United States as a promising nation that embraces refugees fleeing their countries.

\subsubsection{Judgment System}

As stated earlier, Judgment resources can be divided into social esteem and social sanction. It is tried to appraise the behavior of President Trump based on both social esteem and social sanction. There are more negative Judgment resources than positive Judgment resources, and the majority of negative Judgment resources are associated with negative social esteem. The following are some examples that have used Judgment system:

1- The president's callousness and indifference to history.

2- A president who bragged about sexually assaulting women.

3- A volatile and inexperienced president.

4- Republicans in Congress who remain quiet or tacitly supportive of the ban should recognize that history will remember them as cowards.

Example (1) tells us that Trump's indifference to critical historical events, as he issued the executive order on an important day, which is 'Holocaust Remembrance Day.' From the following example, we know that the writer condemns President Trump for showing unethical behaviors pertaining to women and individuals' freedom. Example 3 indicates Trump's inability to handle and manage the countries concerns because of his recklessness and inexperience; this reveals the negative social esteem Judgment that criticized Trump's capacity. Nevertheless, negative judgments were not limited only to President Trump, even the republicans in Congress who remain silent and indirectly accept the ban was criticized as cowards, as the fourth example illustrates.

\subsubsection{Affect System}

The Affect system enables speakers to discuss various types of emotions; it is expressed in various lexicogrammatical structures. According to Hart (2014), expressing effect can be 
expressed as participant descriptions and characteristics, process manners (Affect as quality), the processes themselves (Affect as a process), or modal adjuncts (Affect as a comment). See the following examples:

1- The injury and suffering this ban inflict on families.

2- The cruelty of President Trump's decision.

3- It is extremely dangerous.

In the above examples, we can notice that all the appeared attitudes indicate direct negative Affect on the travel ban and its implications. In examples (1) and (2), the negative Affect is constructed as a grammatical metaphor. According to Halliday (1994), grammatical metaphors include nominalized realizations of qualities and processes. To be specific, in the first example, the writer described the implications of the travel ban, which are the injury and suffering, on the affected families showing his attitude of displeasure with the travel ban, and the second example showed the writer's negative stance of Trump's decision. Furthermore, in the examples (3), negative Affect appeared directly as a quality; the writer describes the ban by employing negative description as in dangerous.

In conclusion, in the New York Times report, both Judgment and Appreciation resources were employed profusely. Concerning Appreciation, the most resources were about the travel ban, and the writer directly and negatively appreciated it. Unlike the Washington Post report, Judgments in the New York Times employed directly towards President Trump, who ordered the ban, and his advocators. On the contrary, we find that Affect resources were employed less than other resources, and they appeared in different grammatical structures. In line with the general attitudinal resources employed in the text, direct negative Affect was employed.

\subsection{Ideological Differences Between the Two Texts}

The analysis of language and the theory of ideology as a social activity of language are two topics that are intimately connected. In their book Language as Ideology, Kress and Hodge (1979) argued that language is ideological since it represents points of view that arise from ideological contexts. Even though many academics consider the word 'ideology' as a broad term, some linguists use it in social or textual contexts. The study of how meaning or ideas influence the conceptions or the behaviors of the individuals and groups that make up the social world has long been a goal of ideology theory. Although the meaning and modalities of ideology have been studied in various ways, Thompson (1984) believes that the study of language must hold a privileged role in such analysis. This section aims to provide an interpretation of the ideological differences that resulted from using different attitudinal resources employed in two American political newspapers, starting with the assumption that linguistic choices in texts can bring ideological meaning.

In analyzing ideology, attitudinal resources like Affect, judgment, and Appreciation are clearly of the utmost importance (Martin \& White, 2005). Both texts employed different negative attitudinal resources towards the travel ban, Trump's administration, and affected refugees. However, the Washington Post report employed negative Appreciation resources towards the 
travel ban more than other resources in the text, indicating the author's strong rejection of the ban. In addition, it focused on the influence of the ban on the affected refugees and their social relationships. In doing so, the writer showing his sympathy and trying to affect readers' emotions and opinions about the travel ban and Trump's administration. Therefore, Appreciation is the most attitude used in the Washington Post that indicates the writer's ideological stance.

Similarly, the New York Times report concentrated on the travel ban's impact on the refugees, and the primary attitudinal resources were employed as negative Appreciation towards the travel ban. The differences between the two text lines in the focus of the New York Times text on the political implications of this ban and its threat to the United States' national security.

Attitudinal assessments are often found attributed to outside sources in the texts, especially in news reporting; this allows writers to say that they are not actually supporting or advocating such evaluations; that is, writers may use it to show if they are more or less consistent with the source cited (Caffarel \& Rechniewski, 2009). This strategy was used extensively in the Washington Post report, while it was never used in the New York Times report. In the Washington Post, the author has cited several resources such as experts from refugees' interviews, Biden's national security adviser, Justice Sonia Sotomayor, his colleagues, and many others sources. All the quotes provided support the writer's opinion of the issue, which are opinions about the travel ban or Trump's fabricated justifications.

\section{Conclusion}

We can conclude from the distribution of attitude systems in the New York Times, and The Washington Post reports that the attitude resources are primarily realized by the Judgment and Appreciation systems, while the Affect system was taking the smallest portion. Besides, there are more negative words among these three systems than positive words in the selected newspaper reports. Further, the predominance of the negative resources in both reports is attributed to the nature of the incident discussed. From the Appraisal theory perspective, both reports' writers criticized the travel ban because of its tragic implications on the banned countries' citizens. They also believe that the travel ban does not express the United States' policies, and it is an extremist order resulting from the reckless president, indicating that he is not worthy of governing the United States. In addition, since it is a public incident, it is common to use verbs or adjectives to characterize it, resulting in more Appreciation resources than other types of resources. Furthermore, the writers did not limit themselves to portraying an incident by employing numerous negative judgments, but rather they attempted to show many ideologies regarding Trump and his government.

\subsection{Limitation of the Study}

This study considers the American newspapers in reporting travel ban incidents, meaning; it is a context-limited to American newspapers. Therefore, further research can be conducted to analyze the incident in different newspapers, such as Al Jazeera newspaper or Al Arabia newspapers, to analyze attitudinal resources from different perspectives. Further, this study is limited to the analysis of attitude subsystems. Hence, this research can be expanded using 
different systems of SFG, such as ideational systems, to examine the ideology of reporting the travel ban incidents in a more in-depth intertextual perspective or corpus-based analysis to observe the pattern of Appraisal distribution in a more recent and broad variety of discourses.

\section{References}

Alhabib, A. A. (2020). Appraisal devices realizing attitudes in Barack Obama's first inaugural speech. International Journal of Linguistics, 12(5), 142-153.

Caffarel, A., \& Rechniewski, E. (2009). A systemic functional approach to analyzing and interpreting ideology: An illustration from French editorials. Revista Alicantina de Estudios Ingleses, 22(2009), 27-43.

De Souza, A. A. (2006). The construal of interpersonal meanings in the discourse of national anthems: An Appraisal analysis. International Systemic Functional Congress, 0(2006), 531-550.

Encyclopedia Britannica online. (2020). The New York Times. Retrieved from https://www.britannica.com/topic/The-New-York-Time

Encyclopedia Britannica online. (2020). The Washington Post. Retrieved from https://www.britannica.com/topic/The-Washington-Post

Fairclough, N. (2003). Analyzing discourse: Textual analysis for social research. London: Routledge.

Halliday, M. A. K. (1994). An introduction to functional grammar. Arnold.

Hart, C. (2014). Discourse, grammar and ideology: Functional and cognitive perspectives. London: Bloomsbury.

Huang, X. (2020). An analysis of the APEC news in Washington Post from the perspective of engagement system based on Appraisal theory. Theory and Practice in Language Studies, 10(9), 1054-1059.

Jin, J. (2019). Political News Discourse Analysis Based on an Attitudinal Perspective of the Appraisal Theory-Taking the New York Times' Report China-DPRK Relations as an Example. Theory and Practice in Language Studies, 9(10), 1357-1361.

Kress, G., \& Hodge, R. (1979). Language as ideology. Routledge \& Kegan Paul.

Martin, J. R. (2000). Beyond exchange: Appraisal systems in English. In S. Hunston, \& G. Thompson (Eds.), Evaluation in text: Authorial stance and the construction of discourse (pp. 142-175). Oxford University Press.

Martin, J. R., \& Rose, D. (2003). Working with Discourse. London: Continuum.

Martin, J. R., \& Rose, D. (2007). Working with discourse: Meaning beyond the clause. Random House.

Martin, J. R., \& White, P. (2005). The Language of evaluation: Appraisal in English. 
Palgrave Macmillan.

Painter, C. (2003). Developing attitude: An ontogenetic perspective on Appraisal. Text, 23(2), 183-209.

Pana, Z., \& Kosickib, G. M. (1993). Framing analysis: An approach to news discourse. Political Communication, 1(1993), 55-75.

Peter, R., \& White, R. (2011). Appraisal. In J. Zienkowski, J. Ola Östman, \& J. Verschueren (Eds.), Discursive pragmatics (pp. 14-33). John Benjamins Publishing Company.

Rui, Z., \& Jingxia, L. (2018). The study on the interpersonal meanings of modality in micro-blogging English news discourse by the case of "Donald Trump's Muslim Entry Ban". Advances in Language and Literary Studies, 9(2), 110-118.

Sahputra, D. (2021). Cabinet Reshuffle News for 2020 in Van Leeweun's Critical Discourse Analysis. Polit Journal: Scientific Journal of Politics, 1(1), 11-18.

Siyou, Z., \& Zhongwen, P. (2018). Analysis of political language based on Appraisal theory: The mutual construction of language and power-taking Xi Jinping and Donald Trump's speeches at world economic forum as examples. International Conference on Social Science and Education Reform, 248(2018), 98-101.

Thompson, G. (2014). Introducing functional grammar. Routledge.

Thompson, J. B. (1984). Studies in the theories of ideology. University of California Press.

Webster, J. J. (2009). Introduction. In M. A. K. Halliday, \& J. Webster (Eds.), Continuum companion to systemic functional linguistics (pp. 1-12). New York: Bloomsbury Publishing.

$\mathrm{Xu}, \mathrm{B}$. (2015). A metafunctional analysis of the news 'ROK, DPRK agree to defuse tension after talks' on China Daily. English Language Teaching, 8(11), 92-98.

Zhang, M. (2014). A critical discourse analysis of political news reports. Theory and Practice in Language Studies, 4(11), 2273. 
Appendix A. Donald Trump's Muslim Ban Is Cowardly and Dangerous y The Editorial board, Jan. 28, 2017

First, reflect on the cruelty of President Trump's decision on Friday to indefinitely suspend the resettlement of Syrian refugees and temporarily ban people from seven predominantly Muslim nations from entering the United States. It took just hours to begin witnessing the injury and suffering this ban inflicts on families that had every reason to believe they had outrun carnage and despotism in their homelands to arrive in a singularly hopeful nation.

The first casualties of this bigoted, cowardly, self-defeating policy were detained early Saturday at American airports just hours after the executive order, ludicrously titled "Protecting the Nation From Foreign Terrorist Entry Into the United States," went into effect. A federal judge in Brooklyn on Saturday evening issued an emergency stay, ordering that those stuck at the airports not be returned to their home countries. But the future of all the others subject to the executive order is far from settled.

It must have felt like the worst trick of fate for these refugees to hit the wall of Donald Trump's political posturing at the very last step of a yearslong, rigorous vetting process. This ban will also disrupt the lives and careers of potentially hundreds of thousands of immigrants who have been cleared to live in America under visas. On Saturday, as mass protests against that ban were held in various cities, the White House scaled back the reach of the policy, though not by much, exempting legal permanent residents.

That the order, breathtaking in scope and inflammatory in tone, was issued on Holocaust Remembrance Day spoke of the president's callousness and indifference to history, to America's deepest lessons about its own values.

The order lacks any logic. It invokes the attacks of Sept. 11 as a rationale, while exempting the countries of origin of all the hijackers who carried out that plot and also, perhaps not coincidentally, several countries where the Trump family does business. The document does not explicitly mention any religion, yet it sets a blatantly unconstitutional standard by excluding Muslims while giving government officials the discretion to admit people of other faiths.

The order's language makes clear that the xenophobia and Islamophobia that permeated Mr. Trump's campaign are to stain his presidency as well. Un-American as they are, they are now American policy. "The United States must ensure that those admitted to this country do not bear hostile attitudes toward it and its founding principles," the order says, conveying the spurious notion that all Muslims should be considered a threat. (It further claims to spare America from people who would commit acts of violence against women and those who persecute people on the basis of race, gender or sexual orientation. A president who bragged about sexually assaulting women and a vice president who has supported policies that discriminate against gay people might well fear that standard themselves.)

The unrighteousness of this new policy should be enough to prompt the courts, Congress and responsible members of Mr. Trump's cabinet to reverse it immediately. But there is an even more compelling reason: It is extremely dangerous. Extremist groups will trumpet this order to 


\section{Macrothink}

International Journal of Linguistics

ISSN 1948-5425

2021, Vol. 13, No. 4

spread the notion, today more credible than ever, that the United States is at war with Islam rather than targeting terrorists. They want nothing more than a fearful, recklessly belligerent America; so, if anything, this ban will heighten their efforts to strike at Americans, to provoke yet further overreaction from a volatile and inexperienced president.

American allies in the Middle East will reasonably question why they should cooperate with, and defer to, the United States while its top officials vilify their faith. Afghans and Iraqis supporting American military operations would be justified in reassessing the merits of taking enormous risks for a government that is bold enough to drop bombs on their homelands but too frightened to provide a haven to their most vulnerable compatriots, and perhaps to them as well. Republicans in Congress who remain quiet or tacitly supportive of the ban should recognize that history will remember them as cowards.

There may be no one better positioned to force a suspension of this policy than Mr. Trump's secretary of defense, Jim Mattis. Mr. Mattis was clear-eyed about the dangers of a proposed Muslim ban during the election, saying that American allies were reasonably wondering if "we have lost faith in reason." He added: "This kind of thing is causing us great damage right now, and it's sending shock waves through this international system."

His silence now is alarming to all who admire his commitment to American security. Mr. Mattis and other senior government officials who know better cannot lend their names to this travesty. Doing so would do more than tarnish their professional reputations. It would make them complicit in abdicating American values and endangering their fellow citizens. 
Appendix B. Trump's Travel Ban Caused Heartache and Suffering. For What? By Ishaan Tharoor Jan. 25, 2021

When you think about the Trump administration's travel bans, think about Hussein Saleh. A U.S. citizen of Yemeni descent, Saleh, 34, has not seen his Yemeni wife and two sons for more than two years after their family was separated when President Donald Trump decided to bar virtually all entry to citizens from a handful of Muslim-majority countries, including war-torn Yemen. "They say, 'Daddy,' you know, 'when are you coming?'” Saleh, who is based in Chicago, told NBC News. "It's hard. I tell them, 'Very soon, very soon I'll come and bring you here with me."”

Think about Afshin Raghebi, a 52-year-old man of Iranian origin stranded in Turkey after his application for a green card - and bid to be reunited with his American wife - was thrown into limbo by Trump. "The U.S., I loved that country. I still love it," he told my colleagues. "They're playing with our lives."

$\mathrm{AD}$

Think about Rand Mubarak, an Iraqi refugee whose father worked as a translator for the U.S. military in Iraq. Their family had fled their homeland to Egypt following death threats and believed they were in line to relocate to the United States given her father's service. But by 2017, their hopes took a severe blow after Trump announced his ban and slowed refugee resettlement to a standstill. Mubarak's father developed a heart condition that required specialized treatment in a U.S. hospital, my colleagues reported. But no special dispensation came, and her father died last year.

Think about Negar Rahmani, a 26-year-old Iranian-born graduate student at the University of Rhode Island who stayed at her academic institution after Trump's executive actions went into effect, aware that a trip home would mean she could be denied reentry to the United States. Then the pandemic hit, and her mother died after contracting covid-19. "I feel like I have been in a cage for four years," Rahmani told the New York Times. "I could have gone back every summer. My mom could have visited me. I feel the travel ban in my bones and skin."

These are just a few names from a vast pool of people whose lives were thrown into disarray by a flick of Trump's pen. The former president had campaigned on the extremist promise of "a total and complete shutdown of Muslims entering the United States." Soon after taking office, he issued an executive order temporarily banning entry and freezing refugee applications from seven Muslim-majority countries. Activists and legal groups mobilized against what many decried as the "Muslim ban"; after a series of challenges in lower courts, Trump's executive order was found to be discriminatory.

But it was upheld by the Supreme Court in 2018 after Trump reissued his proclamations, adding a handful of countries that were not Muslim-majority. By the end of the Trump presidency, citizens from Iran, Libya, Syria, Yemen, Somalia, Nigeria, Myanmar, Eritrea, Kyrgyzstan, Sudan, Tanzania and North Korea were all subject to broad bans on obtaining U.S. visas. 
Trump invoked national security to justify these sweeping prohibitions. Critics argued that there was little to no evidence refugees and immigrants from the targeted countries posed a greater security risk than the overall population. In a 2018 dissent, Justice Sonia Sotomayor wrote that Trump's ban "masquerades behind a facade of national-security concerns" and that "a reasonable observer would conclude" that it was "motivated by anti-Muslim animus."

"Overall, at least 42,650 people — including students, parents, siblings, tourists, children, and businesspeople - have been barred from the United States because of their country of origin, rather than any warning signs in their files," noted a report by the Brennan Center for Justice in 2019, which tracked State Department data starting in 2017.

$\mathrm{AD}$

President Biden repealed the ban on his first day in office. "This ban, which restricted issuance of visas to individuals from many Muslim and African countries, was nothing less than a stain on our nation," Jake Sullivan, Biden's national security adviser, said in a briefing with reporters. "It was rooted in xenophobia and religious animus and [Biden] has been clear that we will not turn our back on our values with discriminatory bans on entry to the United States."

"The Muslim ban showed us America at its worst: nativism, xenophobia, Islamophobia," wrote TV anchor and columnist Mehdi Hasan for MSNBC. "Hundreds of Muslims detained; thousands denied entry; families torn asunder. The much-touted waivers which the Trump administration had promised, and which [Supreme Court Chief Justice John] Roberts had relied upon for his ruling, never materialized while studies suggested this was, in fact, an explicit attack on Muslim immigrants."

For myriad noncitizens, as well as the Americans with whom their lives were intertwined, there's no reversing Trump's actions. "There will be no regaining what was lost: the moments with loved ones, the money spent on visits to stranded partners or far-flung consulates, the opportunities to live in the United States that were dangled, then dashed or delayed," my colleagues wrote.

And for what gain? It's impossible to prove that America was made safer by inflicting this torment on whole communities abroad. But it's also hard to say that Trump paid much of a political price for doing so. According to an ABC-Ipsos poll, 55 percent of Americans approve of Biden repealing the travel bans - a slender, partisan majority that suggests tens of millions of Americans either have no qualms exacting such pain on strangers, or no idea about the misery the travel bans caused and the severity of the immigration system that was already in place before Trump took office.

Nevertheless, advocates are calling for the Biden administration to press ahead with a more liberal agenda. Beyond simply scrapping Trump's policies, they want Biden to expand refugee resettlement, in coordination with other wealthy nations, to reckon with the unprecedented size of the global refugee population. They also are urging Biden officials to revise older immigration protocols they believe show bias against Arab and Muslim applicants.

"We don't want to simply roll back to the status-quo pre-Trump," Diala Shamas, a human 


\section{Macrothink}

International Journal of Linguistics

ISSN 1948-5425 2021, Vol. 13, No. 4

rights lawyer at the Center for Constitutional Rights, told the Middle East Eye. "Many of us have been working really hard to remove all sorts of discriminatory aspects of our immigration system before Trump ever came along."

\section{Copyrights}

Copyright for this article is retained by the author(s), with first publication rights granted to the journal.

This is an open-access article distributed under the terms and conditions of the Creative Commons Attribution license (http://creativecommons.org/licenses/by/4.0/) 